Proc. Estonian Acad. Sci. Biol. Ecol., 2003, 52, 3, 254-267

\title{
Alien species introductions in the eastern Gulf of Finland: current state and possible management options
}

\author{
Vadim E. Panov*, Dmitry E. Bychenkov, Nadya A. Berezina, and \\ Alexey A. Maximov \\ Zoological Institute of the Russian Academy of Sciences, Universitetskaya nab. 1, 199034 \\ St. Petersburg, Russia \\ Received 9 January 2003, in revised form 16 May 2003

\begin{abstract}
Recent studies showed that the eastern Gulf of Finland should be considered as a "hot spot" in the Baltic Sea area, taking into account the high rate of alien species introductions, the negative environmental impacts of established alien species, and rapidly increasing export-oriented shipping. At minimum, 14 new species have established in the eastern Gulf of Finland during the last two decades, including several invasive species. Alien species are playing an important role in the structural and functional organization of communities, specifically in the littoral zone, but this role has not been fully evaluated yet. Rapid development of new ports in the eastern Gulf of Finland will result in manifold increase in the volumes of discharged ballast waters, as well as in associated risk of new invasions of harmful aquatic species in the near future. Development of effective management options to control established nuisance species and to prevent or minimize the risk of new invasions is urgently needed.
\end{abstract}

Key words: Gulf of Finland, biological invasions, alien species, environmental effects, ballast water management.

\section{INTRODUCTION}

The introduction of alien species, which can be considered as biological pollution, is a growing environmental issue worldwide. The rate of alien species introductions in aquatic ecosystems around the world has accelerated significantly during the last decades, mainly due to the intensification of both shipping activity and uncontrolled release of ballast water of ships. Invasions of alien species adversely affect biological diversity and the structure and functioning of aquatic ecosystems. Pathogens and toxic algae are a direct threat to human health. In

\footnotetext{
*Corresponding author, gaas@zin.ru
} 
contrast with other anthropogenic impacts, consequences of biological pollution for natural ecosystems are mainly irreversible (CBD Special Issue on Alien Species, 2002).

The introduction of invasive marine species into new environments by ships' ballast water, attached to ships' hulls, and via other vectors has been identified as one of the four greatest threats to the world's oceans. The other three are landbased sources of marine pollution, overexploitation of living marine resources, and physical alteration/destruction of marine habitat. Shipping transfers approximately 3 to 5 billion tonnes of ballast water internationally each year. A similar volume may also be transferred domestically within countries and regions each year (GloBallast, 2002).

During the last decades invasion rates of alien species into the Baltic Sea ecosystems, associated with shipping, increased significantly. It is believed that about 100 aquatic invaders occur in the Baltic Sea, with 56 species first recorded during 1950-2002 (Baltic Sea Alien Species Database, 2002). Several invasive alien species, whose impact on Baltic Sea ecosystems seems to be very important, are established in the Gulf of Finland: the Ponto-Caspian zebra mussel Dreissena polymorpha and the predatory cladoceran Cercopagis pengoi, the North American polychaete Marenzelleria viridis, the Chinese mitten crab Eriocheir sinensis, and others (Leppäkoski et al., 2002). Taking into account the present intensive shipping activity and future development of new ports in the eastern Gulf of Finland, this gulf can be identified as "a hot spot" area in the Baltic Sea in terms of vulnerability to alien species and high potential of established invaders who negatively affect the ecosystems (Panov et al., 1999a). Introductions of alien species along with severe eutrophication can be considered as the most challenging environmental problems of the eastern Gulf of Finland, which require different approaches to their management (Panov et al., 2002a).

This paper provides a brief overview of the present invasion status of the eastern Gulf of Finland $\left(27^{\circ} \mathrm{E}\right.$ longitude can be considered as the approximate western boundary of the eastern part of the gulf) and the existing management efforts, and discusses main future directions of research and management, including possible international efforts in combating this transboundary issue.

\section{CURRENT STATE OF ALIEN SPECIES INTRODUCTIONS IN THE EASTERN GULF OF FINLAND}

Studies of biodiversity of the eastern Gulf of Finland and its basin, conducted during the last decade of the 20th century in the frameworks of several national and international programmes, revealed that 10 potentially invasive alien species (alien species harmful to natural biodiversity, biological resources, and economy) have established in the open and coastal waters of the eastern Gulf of Finland and inland waters in its basin during a comparatively short period of time (Panov, 1996; Panov et al., 1996, 1997, 2001; Alimov et al., 1998; Orlova et al., 1999a). 
These species include aquatic organisms of Ponto-Caspian origin such as the hydroid Cordylophora caspia Pallas, the zebra mussel Dreissena polymorpha Pallas, the fishhook spiny waterflea Cercopagis pengoi (Ostroumov), the amphipod Pontogammarus robustoides (G. O. Sars); the Atlantic polychaete Marenzelleria viridis (Verrill) and the barnacle Balanus improvisus Darwin; the New Zealand mud snail Potamopyrgus antipodarum (Gray); the Asian Chinese mitten crab Eriocheir sinensis (Milne-Edwards); the Baikalian amphipod Gmelinoides fasciatus (Stebbing); and the Amur sleeper fish Perccottus glenii Dybows. Other alien species established in the eastern gulf include the Ponto-Caspian oligohaetes Potamothrix vejdovskyi (Hrabe), Potamothrix heukeri (Bret.), Paranais frici Hrabe, and the Atlantic copepod Acartia tonsa Dana. Several alien species of fish, intentionally introduced in the eastern Gulf of Finland and its basin (Acipenser ruthenus L., Acipenser baeri Brandt, Acipenser gueldenstaedti Brandt, Parasalmo mykiss gairdneri (Richardson), Coregonus autumnalis migratorins (Georg.), Coregonus nasus (Pallas), Coregonus muksun (Pallas), Coregonus peled (Gmelin), Catostomus catostomus rostratus (Tilesius), Cyprinus carpio L.), are rare and most likely should not be regarded as established alien species in the region. Ballast waters of ships are considered to be a main vector of alien species introductions in the gulf: at least 12 established alien species are believed to have been introduced with ships (Panov et al., 1999b, 2002a).

The zebra mussel D. polymorpha, the fishhook waterflea $C$. pengoi, and the Chinese mitten crab E. sinensis are regarded as the most harmful invasive species in the world. They are included in the list of "One Hundred of the World's Worst Invasive Alien Species" (ISSG Global Invasive Species Database) and listed among ten of the "Most Unwanted" alien species transferred with ballast waters of ships (GloBallast, 2002). The present distribution of these species in the eastern Gulf of Finland is provided in Fig. 1.

Settlements of D. polymorpha in the eastern Gulf of Finland were first found in 1990 (Antsulevich \& Lebardin, 1990). A year before numerous shells of the zebra mussel were recorded in storm casts on beaches and one living adult specimen was caught by the first author with sampling dredge in the littoral zone of the inner Neva estuary in the Resort District of St. Petersburg. It was suggested that D. polymorpha had invaded the eastern Gulf of Finland by the mid-1980s (Orlova \& Panov, 2003). In 1995 settlements of this alien species were first found in the Finnish waters of the eastern Gulf of Finland (Valovirta \& Porkka, 1996), most likely as a result of passive drift of larvae, originating from populations initially established along the northern shore of the Neva estuary (Orlova \& Panov, 2003). In Estonian waters of the Gulf of Finland Dreissena was found only in one locality of Narva Bay (Fig. 1) at comparatively low densities of 100 ind. $\mathrm{m}^{-2}$ (Kotta et al., 1998). At present, Dreissena is a dominating species in hard-bottom littoral communities in the Neva estuary at depths of 1.5-5.0 m, exceeding 2000 ind. $\mathrm{m}^{-2}$ in some locations. Dreissena may significantly affect the environmental quality in near-shore waters, specifically via recycling nutrients and contributing to decaying organic material on beaches after storm events (Orlova et al., 1999b; Panov et al., 2002a). In the eastern Gulf of Finland this 


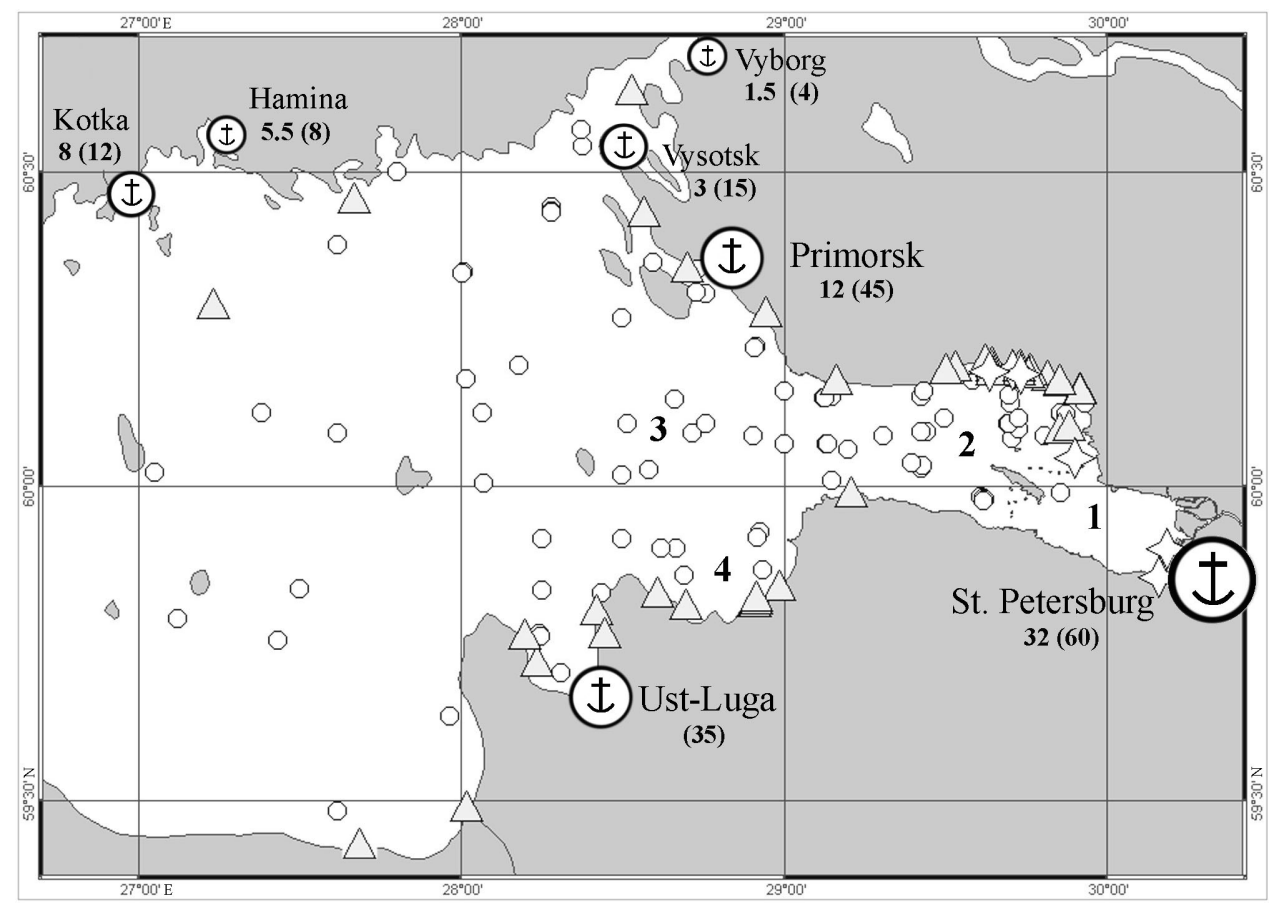

Fig. 1. Distribution of Cercopagis pengoi (circles), Dreissena polymorpha (triangles), and Eriocheir sinensis (stars) in the eastern Gulf of Finland (1 - Neva Bay, 2 - inner Neva estuary, 3 - outer Neva estuary, 4 - Koporskaya Bay). Data on Dreissena distribution in Finnish and Estonian waters are from Valovirta \& Porkka (1996) and Kotta et al. (1998), respectively. Numbers under the names of the ports indicate their present and perspective by 2010 (in brackets) capacities (in million tonnes per year).

species is also causing technical problems, fouling water intake constructions of the Leningrad nuclear power station (Alimov et al., 1998) and a fish breeding farm in the lower reaches of the Narva River.

After its first records in 1992 both in the Gulf of Riga and the Gulf of Finland another Ponto-Caspian invasive species, the predatory cladoceran Cercopagis pengoi, was first found in the eastern Gulf of Finland in 1995, already at high densities (Ojaveer \& Lumberg, 1995; Panov et al., 1996, 1999b, 2002a). Since 1995 C. pengoi has become an abundant zooplankton species in the Neva estuary (Krylov et al., 1999; Litvinchuk et al., 2001) and Finnish waters of the eastern Gulf of Finland (Antsulevich \& Välipakka, 2000) (Fig. 1). This invasive species may adversely affect native zooplankton in the Neva estuary by predation (Telesh et al., 2001). Biofouling of fishing nets by $C$. pengoi is already a serious problem in the eastern Gulf of Finland. Economic losses by only one fishing farm, located at the northern shore of the outer Neva estuary in the vicinity of Primorsk oil terminal, from 1996 to 2000 exceeded US\$ 50000 due to a drastic decline in the fish catches and the cost of unsuccessful fishing efforts (Panov et al., 1999b, 2002a). 
The Chinese mitten crab Eriocheir sinensis was first recorded in the eastern Gulf of Finland in 1980. Most likely its invasion to the Gulf of Finland was a result of range expansion of the southern Baltic population of this species, initially introduced in the German coastal waters (North Sea) in the early 20th century with ballast waters of ships (Gollasch, 1999). In the late 1990s adult specimens of E. sinensis were first registered in inland waters of the Gulf of Finland basin, including the Vuoksa River and Lake Ladoga (Alimov et al., 1998). In 2002 numerous records in fishing nets in the Russian coastal waters of the eastern Gulf of Finland were made, specifically in freshwater Neva Bay and the inner Neva estuary (Fig. 1). These records may indicate a significant increase in the population density of this species in the Gulf of Finland by 2002. Further increase in the abundance of $E$. sinensis may result in environmental and economic problems usually associated with this invasive species, including extinction of native species, competition for space and food with other species, damaging burrowing activities, feeding on fish caught in nets, etc. (Gollasch, 1999).

The North American polychaete Marenzelleria viridis was first recorded in Russian waters of the eastern Gulf of Finland in July 1996 (Lyakhin et al., 1997). During 1997-2002 this species successfully established in the bottom communities of the eastern gulf, and became a dominating species in some locations, reaching densities up to 500 ind. $\mathrm{m}^{-2}$ in 2001. The bottom macrofauna of the eastern Gulf of Finland is very poor and bottom communities consist of only a few species (Maximov, 1997). Therefore the successful invasion of M. viridis must have a great impact on the native benthos. Adverse effects of this species on the indigenous fauna were reported in the Vistula and Curonian lagoons, where M. viridis replaced the native species (Zmudzinski, 1996; Zmudzinski et al., 1996). $M$. viridis may avoid fish predation, because it penetrates the sediment deeper than Baltic species (Winkler \& Debus, 1996). Thereby replacement of native species may result in a decrease of food resources for some fishes. In the future this invasion may bring about significant alterations of bottom communities of the Gulf of Finland, including replacement of some native species (Kotta \& Kotta, 1998; Kotta, 2000). Enhancement of eutrophication of the gulf is also possible in case of increasing nutrients load from bottom sediments due to the burrowing activity of $M$. viridis.

Alien amphipods are among the most recent invaders established in the eastern Gulf of Finland. The Baikalian amphipod Gmelinoides fasciatus was first found in Neva Bay in 1996, and in 1999 in the adjacent littoral habitats in the inner Neva estuary, as a result of secondary introduction from Lake Ladoga (Panov, 1996; Panov \& Berezina, 2002; Berezina \& Panov, 2003a). Most likely this introduction had taken place in the early 1990s, and in a short period of time G. fasciatus replaced the native amphipod Gammarus lacustris in Neva Bay, like it happened in large lakes in the Gulf of Finland basin (Panov et al., 2000; Panov \& Berezina, 2002). Another invasive species of amphipods, Ponto-Caspian Pontogammarus robustoides, was first found by the author in Neva Bay in 1999 (Panov et al., 2002a). At present these alien species of amphipods are the 
dominating species in some locations of the littoral zone of Neva Bay and the inner Neva estuary, significantly influencing the food web dynamics in the littoral communities (Berezina \& Panov, 2003b).

Other invasive alien species of invertebrates, the hydroid Cordylophora caspia, the barnacle Balanus improvisus, and the New Zealand mud snail Potamopyrgus antipodarum are abundant locally in the littoral communities of the eastern Gulf of Finland. The Amur sleeper Perccottus glenii, one of the most invasive fishes in Russia, is currently increasing in abundance, specifically in the littoral zone of Neva Bay, which may result in significant changes in the native fish fauna.

In general, biological invasions have resulted in the development of new communities in coastal waters of the eastern Gulf of Finland, with a dominance of Cordylophora caspia, Dreissena polymorpha, Potamopyrgus antipodarum, and Balanus improvisus in more marine areas, and Gmelinoides fasciatus and Pontogammarus robustoides in oligohaline and freshwater locations. In pelagic communities of the gulf, the predatory cladoceran Cercopagis pengoi has become well established, causing serious economic problems for coastal fisheries as a biofouler of fishing nets. Other highly invasive alien species, the Atlantic polychaete Marenzelleria viridis, the Chinese mitten crab Eriocheir sinensis, and the Far East fish Perccottus glenii are rapidly expanding in the gulf. Alien species are likely to play an important role in the structural and functional organization of the eastern Gulf of Finland coastal ecosystems, but so far this role has not been properly evaluated (Panov et al., 2002a).

\section{EASTERN GULF OF FINLAND AS A DONOR AREA OF INVASIVE SPECIES}

As it has been shown recently, the Neva estuary can be a source of alien species for the North American Great Lakes. The predatory cladoceran Bythotrephes longimanus, a native species to Lake Ladoga and the Neva estuary, invaded the Great Lakes with the ballast water of ships returning from the Leningrad (St. Petersburg) port in the early 1980s, as suggested by Sprules et al. (1990). Recently this hypothesis has been supported by the genetic study of Bythotrephes, confirming the existence of an eastern Baltic Sea-North American Great Lakes invasion corridor (Berg et al., 2002).

A possibility that the eastern Gulf of Finland serves as a source of secondary introductions of alien species to other aquatic ecosystems worldwide also exists. Also the appearance of the fishhook waterflea Cercopagis in the Great Lakes in 1998 (MacIsaac et al., 1999) can be attributed to the existence of an invasion corridor between the eastern Baltic and the North-American Great Lakes (Panov et al., 1999b). Most likely, the population of Cercopagis in the Great Lakes originates from the Baltic Sea population, namely from the Neva estuary in the eastern Gulf of Finland (Cristescu et al., 2001). The C. pengoi population 
established in the Neva estuary showed a remarkable reproductive strategy, producing a large number of resting eggs during summer months (Panov et al., 1996; Krylov \& Panov, 1998). It has been suggested that this large pool of resting eggs increases the risk of $C$. pengoi being dispersed by ships' ballast water from the estuary (Panov et al., 1996). In summer 1998 C. pengoi was found in Lake Ontario, snagged on sport fishing lines (MacIsaac et al., 1999; Grigorovich et al., 2000). The invasion of $C$. pengoi to the Lawrentian Great Lakes demonstrates the limited effectiveness of ballast water exchange programmes in preventing introductions of aquatic invertebrates producing resting eggs that may accumulate in sediments of ballast tanks (Panov et al., 1999b).

Increasing abundance of other invasive species in the vicinity of ports in the eastern Gulf of Finland, specifically of the polychaete Marenzelleria viridis, the zebra mussel Dreissena polymorpha, the mitten crab Eriocheir cinensis, the amphipods Pontogammarus robustoides and Gmelinoides fasciatus, may result in future transfer of these species to other distant areas. Risk of invasive species transfer from the gulf to other regions is gradually increasing with the growth of shipping activities. Considering the wide environmental tolerance (euryhalinity, resistance to pollution) in most established invasive species, the eastern Gulf of Finland may serve in the future as an important donor area of these species for other European coastal and inland waters and worldwide.

\section{DEVELOPMENT OF NEW PORTS IN THE EASTERN GULF OF FINLAND AS A RISK FACTOR FOR NEW INVASIONS}

The port of St. Petersburg, the main port in the eastern Gulf of Finland, and other ports in this area have a strategic position in the Baltic Sea, being located at the intersection of main transoceanic (from the Atlantic Ocean) and transcontinental (from the basins of the White, Black, and Caspian seas) shipping routes (Fig. 1). The St. Petersburg Marine Port is expected to double its capacity in the future, which may reach 60 million tonnes per year by 2010. Other Russian ports in this area are also rapidly developing. In total, the shipping traffic in the eastern gulf may increase 3 fold in less than 10 years, and capacities of all ports in the eastern Gulf of Finland may exceed 160 million tonnes per year (Fig. 1). According to estimations the capacities of three major ports in the Gulf of Finland St. Petersburg, Ust-Luga, and Primorsk - may exceed 100 million tonnes per year by 2010 (Rumyantsev, 1999). For the whole Gulf of Finland the shipping activity already doubled in the last ten years, and a further significant increase is expected by 2010, specifically for oil transportation, whose increase from 1990 to 2010 was estimated as more than 5 fold (Fig. 2) (EuroGOOS, 2000). Russian ports in the eastern Gulf of Finland are the main contributors to the increase in oil transportation in the gulf, accounting for more than 4 fold increase in the period 1995-2005 (Fig. 2) (Statistical Analyses of Baltic Maritime Traffic, 2002). 
(a)

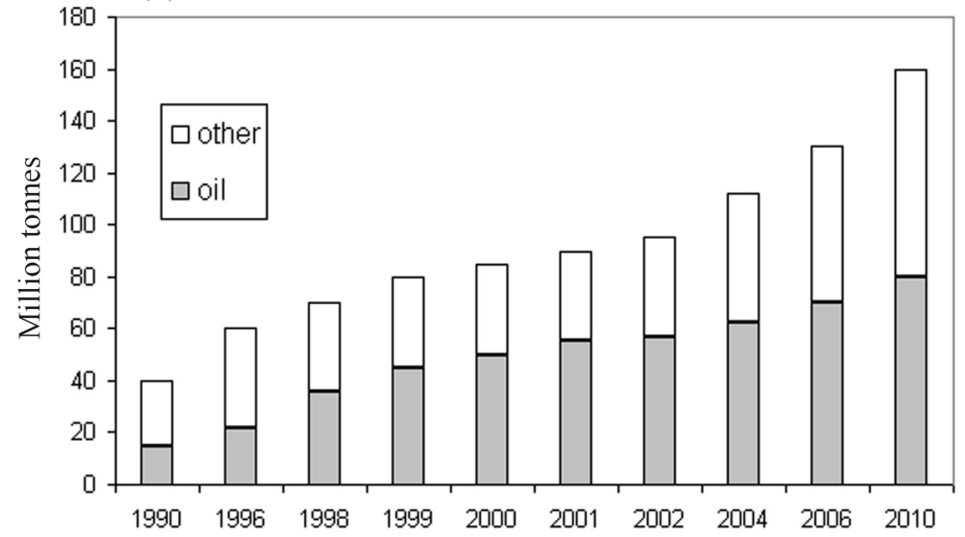

(b)

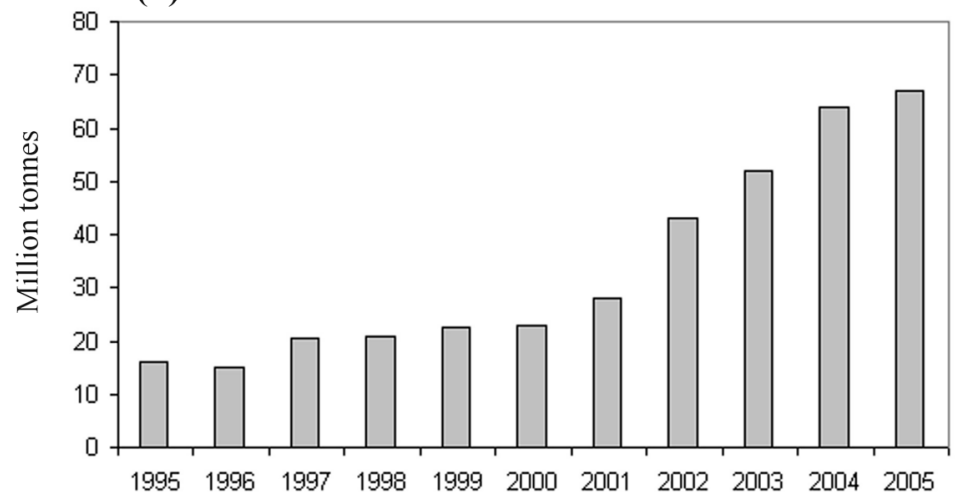

Fig. 2. Development of ship traffic in the Gulf of Finland: (a) - oil and other cargo transportation in the Gulf of Finland from 1990 to 2010 (modified from EuroGOOS, 2000); (b) - oil transportation by ports in the Russian part of the eastern Gulf of Finland from 1995 to 2005 (modified from Statistical Analyses of Baltic Maritime Traffic, 2002).

These developments have resulted in a rapid increase in the volumes of released ballast waters, and in associated risk of introduction of potentially harmful pathogens and invasive aquatic species into the eastern Gulf of Finland. Considering absence of ballast water management, the present drastic increase in the amounts of released ballast waters may result in catastrophic and irreversible changes in the Gulf of Finland ecosystems and develop into a most serious environmental problem of the region in the near future (Panov et al., 1999a, 2002a).

Port areas in the eastern Gulf of Finland should be considered primary risk areas for future invasions. Also Koporskaya Bay, which receives thermal discharges from the Leningrad nuclear power plant, should be regarded as a "hot spot" near the port areas (Fig. 1). The thermal discharges may provide favourable conditions for initial establishment of new alien species populations (Panov et al., 1999b). 


\section{FUTURE DIRECTIONS OF RESEARCH AND MANAGEMENT OF ALIEN SPECIES IN THE EASTERN GULF OF FINLAND}

The scientific community expressed its concern regarding alien species introductions in the Gulf of Finland basin as early as in 1998 in a special publication, which first described the problem for decision-makers and put forward a question on the development and implementation of a special regional programme devoted to the issue (Alimov et al., 1998). Organization of alien species monitoring and alien species risk assessment, development of preventive management options, and information dissemination were suggested as priority areas for this programme. However, until recently management efforts were mainly limited to collection of information on ship traffic by the Baltic Maritime Inspection of the Russian Ministry of Natural Resources. In 2002, the Administration of St. Petersburg supported the first study devoted to elaboration of protective measures against biological pollution of the water system Lake Ladoga-Neva River-Neva Bay-eastern Gulf of Finland (Alimov et al., 2002).

The management of alien species introductions requires specific approaches and should mainly be based on preventive actions, including ballast water control. Special research efforts are needed that are directed towards environmental impact assessment and development of a management plan to control established nuisance species, such as D. polymorpha and C. pengoi, and to prevent or minimize the risk of new invasions in the Neva estuary. These research efforts should include collection of data on the distribution of alien species in the eastern Gulf of Finland, development of a database on alien species in the form of geographic information systems (GIS), analysis of the biology and environmental requirements of target alien species, assessment of the environmental impact of alien species on natural communities and ecosystems, assessment of the socio-economic impact of alien species, development of a cost-effective monitoring programme for natural biodiversity and for alien species in aquatic ecosystems, risk assessment of aquatic alien species, and dissemination of information on the problem for the public (Panov et al., 2002a). During 2002-04 these research efforts in the eastern Gulf of Finland will be partly funded by the Russian Federal Government in the frameworks of the project "Assessment of Ecosystem Impacts of Alien Species in the Baltic Sea Basin", and by the Administration of St. Petersburg, currently supporting monitoring of invasive aquatic species (Regional Biological Invasions Center, 2002a).

\section{INTERNATIONAL COLLABORATION IN ALIEN SPECIES RESEARCH AND MANAGEMENT}

Introduction of alien species is a transboundary issue, and effective international collaboration is essential for elaboration of effective management measures (Panov et al., 2002b). Development and implementation of a special Finnish-RussianEstonian action plan for prevention and control of alien species introductions 
in the Gulf of Finland area was suggested by V. Panov, E. Leppäkoski, and H. Ojaveer as early as in 1999 (Panov et al., 1999a). According to these suggestions, this action plan should include development of databases on alien species in a form of specialized geographic information systems (GIS); development of cost-effective monitoring programs; assessment of environmental and economic threats posed by alien species; developing of control and preventive measures, including ballast waters regulations. However, until recently this collaboration has been limited to the study of the distribution and biology of alien species in the Neva estuary littoral zone, conducted in 2000-02 in the frameworks of the Gulf of Finland Littoral Ecology Project, supported by the Finnish Ministry of Environment and Tor and Maj Nessling Foundation (Regional Biological Invasions Center, 2002a).

After the Baltic Regional Workshop on Ballast Water Management, organized by the International Maritime Organisation (IMO) in 2001 in Tallinn, Estonia (Raaymakers, 2002), an international project proposal entitled "Alien Invasive Species in the Eastern Baltic Sea: Monitoring and Assessment of Ecological Impacts" was elaborated, which involves research teams from Estonia, Finland, Latvia, Lithuania, and Russia. Development of a monitoring system for aquatic invasive species and assessment of their environmental impacts in the eastern Baltic Sea in order to provide essential information for invasive species management are the main goals of the proposed international project (Regional Biological Invasions Center, 2002a).

Development of a joint information system on invasive species is one of the key objectives of the project. At the beginning of 2003, the on-line searchable geographic information system "Invasive Species of the Baltic Sea" was developed as part of this international initiative. The on-line GIS application includes some functions for on-line management of geo-referenced data on the distribution of invasive aquatic species in the Gulf of Finland, and may in the future serve as an effective regional management tool (Regional Biological Invasions Center, $2002 \mathrm{~b}$ ). Successful implementation of the project goals will greatly facilitate development and implementation of the appropriate management options both on the national and international levels in the Gulf of Finland area. Future trilateral Estonian-Finnish-Russian collaboration on the issue of alien species introductions in the Gulf of Finland can be further developed using this project as a main framework. Timely incorporation of geo-referenced data from invasive aquatic species monitoring into a joint open database is one of the most challenging goals, and elaboration of effective mechanisms for achieving this goal should be considered as one of the future priorities for trilateral collaboration in this area.

\section{ACKNOWLEDGEMENTS}

We thank Dr. Jonne Kotta for criticism in reviewing the paper and his valuable comments. Support for the present study was provided by the Russian Federal contract No. 43.073.1.1.2511, grants from the Presidium of the Russian 
Academy of Sciences on Biodiversity Conservation, and St. Petersburg Scientific Center of the Russian Academy of Sciences, Administration of St. Petersburg, and Maj and Tor Nessling Foundation.

\section{REFERENCES}

Alimov, A. F., Panov, V. E., Krylov, P. I., Telesh, I. V., Bychenkov, D. E., Zimin, V. L., Maximov, A. A. \& Filatova, L. A. 1998. The problem of anthropogenic introductions of non-indigenous organisms in the Gulf of Finland basin. In Ecological Situation in St. Petersburg and Leningrad Region in 1997. Analytic Review (Frolov, A. K., ed.), pp. 243-248. St. Petersburg (in Russian).

Alimov, A. F., Panov, V. E., Florinskaya, T. M. \& Emelkina, E. G. 2002. Protection of water system Lake Ladoga - Neva River - Neva Bay - eastern Gulf of Finland from biological pollution. In Proceedings of the Conference "Environmental safety of St. Petersburg", September 23, 2002, pp. 16-24. St. Petersburg (in Russian).

Antsulevich, A. E. \& Lebardin, M. V. 1990. "Wandering shell” Dreissena polymorpha (Pall.) is close to Leningrad. Vestn. Leningr. Univ. Biol. Ser. 3, 4(24), 109-110 (in Russian).

Antsulevich, A., \& Välipakka, P. 2000. Cercopagis pengoi - new important food object of the Baltic herring in the Gulf of Finland. Internat. Rev. Hydrobiol., 85(5-6), 609-619.

Baltic Sea Alien Species Database. 2002. Olenin, S., Leppäkoski, E. \& Daunys, D. (eds). http://www.ku.lt/nemo/mainnemo.htm

Berezina, N. A. \& Panov, V. E. 2003a. Distribution, population structure and salinity resistance of the invasive amphipod Gmelinoides fasciatus (Stebbing) in the Neva Estuary (Gulf of Finland, Baltic Sea). Hydrobiologia, in press.

Berezina, N. A. \& Panov, V. E. 2003b. Establishment of new gammarid species in the eastern Gulf of Finland (Baltic Sea) and their effects on littoral communities. Proc. Estonian Acad. Sci. Biol. Ecol., 52, 284-304.

Berg, D. J., Garton, D. W., MacIsaac, H. J., Panov, V. E. \& Telesh, I. V. 2002. Changes in genetic structure of North American Bythotrephes populations following invasion from Lake Ladoga, Russia. Freshwater Biol., 47(2), 275-282.

CBD Special Issue on Alien Species, 2002. http://www.biodiv.org/programmes/cross-cutting/ alien/default.asp

Cristescu, M. E. A., Hebert, P. D. N., Witt, J. D. S., MacIsaac, H. J. \& Grigorovich, I. A. 2001. An invasion history for Cercopagis pengoi based on mitochondrial gene sequences. Limnol. Oceanogr., 46, 224-229.

EuroGOOS Publication No. 14, January 2000. http://www.boos.org (BOOS plan).

GloBallast. 2002. Global Ballast Water Management Programme. http://globallast.imo.org

Gollasch, S. 1999. Eriocheir sinensis (Milne-Edwards, 1854). In Case Histories on Introduced Species: Their General Biology, Distribution, Range Expansion and Impact (Gollasch, S., Minchin, D., Rosenthal, H. \& Voigt, M., eds.), pp. 55-60. Logos-Verl., Berlin.

Grigorovich, I. A., MacIsaac, H. J., Rivier, I. K., Aladin, N. V. \& Panov, V. E. 2000. Comparative biology of the predatory cladoceran Cercopagis pengoi from Lake Ontario, Baltic Sea and Caspian Sea. Arch. Hydrobiol., 149, 23-50.

ISSG Global Invasive Species Database. http://www.issg.org/database

Kotta, J. 2000. Impact of eutrophication and biological invasions on the structure and functions of benthic macrofauna. Diss. Biol. Univ. Tartu, 63.

Kotta, J. \& Kotta, I. 1998. Distribution and invasion ecology of Marenzelleria viridis in the Estonian coastal waters. Proc. Estonian Acad. Sci. Biol. Ecol., 1998, 47, 212-220.

Kotta, J., Orav, H. \& Kotta, I. 1998. Distribution and filtration activity of the zebra mussel, Dreissena polymorpha, in the Gulf of Riga and the Gulf of Finland. Proc. Estonian Acad. Sci. Biol. Ecol., 1998, 47, 32-41. 
Krylov, P. I. \& Panov, V. E. 1998. Resting eggs in the life cycle of Cercopagis pengoi, a recent invader of the Baltic Sea. Arch. Hydrobiol. Spec. Issues Advanc. Limnol., 52, 383-392.

Krylov, P. I., Bychenkov, D. E., Panov, V. E., Rodionova, N. V. \& Telesh, I. V. 1999. Distribution and seasonal dynamics of the Ponto-Caspian invader Cercopagis pengoi (Crustacea, Cladocera) in the Neva Estuary (Gulf of Finland). Hydrobiologia, 393, 227-232.

Leppäkoski, E., Gollasch, S., Gruszka, P., Ojaveer, H., Olenin, S. \& Panov, V. 2002. The Baltic - a sea of invaders. Can. J. Fish. Aquat. Sci., 59, 1175-1188.

Litvinchuk, L. F., Rivier, I. K. \& Panov, V. E. 2001. Dynamics of abundance, structure of population and fecundity of Ponto-Caspian cladoceran, Cercopagis pengoi (Ostroumov, 1891) (Polyphemoidea, Cercopagidae) in the eastern Gulf of Finland, the Baltic Sea. Biol. Inland Waters, 1, 57-62 (in Russian).

Lyakhin, Y. I., Makarova, S. V., Maximov, A. A., Savchuk, O. P. \& Silina, N. I. 1997. Ecological situation in the eastern Gulf of Finland in July 1996. In Ecosystem Models. Assessment of the Contemporary State of the Gulf of Finland. Part 2. Hydrometeorological, Hydrochemical, Hydrobiological, Geological Conditions and Water Dynamics of the Gulf of Finland (Savchuk O. P. \& Davidan, I. N., eds.), pp. 416-434. Gidrometeoizdat, St. Petersburg (in Russian).

MacIsaac, H. J., Grigorovich, I. A., Hoyle, J. A., Yan, N. D. \& Panov, V. E. 1999. Invasion of Lake Ontario by the Ponto-Caspian cladoceran predator Cercopagis pengoi. Can. J. Fish. Aquat. Sci., 56, 1-5.

Maximov, A. A. 1997. Macrozoobenthos of the eastern Gulf of Finland. Ecological situation in the eastern Gulf of Finland in July 1996. In Ecosystem Models. Assessment of the Contemporary State of the Gulf of Finland. Part 2. Hydrometeorological, Hydrochemical, Hydrobiological, Geological Conditions and Water Dynamics of the Gulf of Finland (Savchuk O. P. \& Davidan, I. N., eds.), pp. 405-416. Gidrometeoizdat, St. Petersburg (in Russian).

Ojaveer, H. \& Lumberg, A. 1995. On the role of Cercopagis (Cercopagis) pengoi (Ostroumov) in Pärnu Bay and the NE part of the Gulf of Riga ecosystem. Proc. Estonian Acad. Sci. Ecol., 5, 20-25.

Orlova, M. I. \& Panov, V.E. 2003. Establishment of the zebra mussel, Dreissena polymorpha Pallas, in the Neva Estuary (Gulf of Finland, Baltic Sea): distribution, population structure and possible impact on local unionid bivalves. Hydrobiologia, in press.

Orlova, M. I., Panov, V. E., Krylov, P. I., Telesh, I. V. \& Khlebovich, V. V. 1999a. Changes in plankton and benthic communities in the eastern Gulf of Finland, associated with biological invasions. Proc. Zool. Inst., 279, 305-325 (in Russian).

Orlova, M. I., Anokhina, L. E., Panov, V. E., Nekrasov, A. V. \& Klimentenok, S. N. 1999b. Preliminary environmental state assessment for littoral zone in Resort District of St. Petersburg. Balt. Float. Univ. Res. Bull., 3, 37-42.

Panov, V.E. 1996. Establishment of the Baikalian endemic amphipod Gmelinoides fasciatus in Lake Ladoga. Hydrobiologia, 322, 187-192.

Panov, V. E. \& Berezina, N. A. 2002. Invasion history, biology and impacts of the Baikalian amphipod Gmelinoides fasciatus. In Invasive Aquatic Species of Europe - Distribution, Impacts and Management (Leppäkoski, E., Gollasch, S. \& Olenin, S., eds.), pp. 96-103. Kluwer Acad. Publ., Dordrecht, The Netherlands.

Panov, V. E., Krylov, P. I. \& Telesh, I. V. 1996. The Caspian predatory cladoceran Cercopagis pengoi invades the Gulf of Finland. BFU Res. Bull., 2, 80-81.

Panov, V. E., Alimov, A. F., Balushkina, E. V., Golubkov, S. M., Nikulina, V. N., Telesh, I. V. \& Finogenova, N. P. 1997. Monitoring of biodiversity of bottom and plankton communities in the Neva Estuary. In Monitoring of Biodiversity (Sokolov, V. E., Reshetnikov, Y. S. \& Shatunovski, M. I., eds.), pp. 288-294. Moscow (in Russian).

Panov, V., Leppäkoski, E. \& Ojaveer, H. 1999a. Introduction of alien species into the Gulf of Finland - an increasing environmental problem. In Regional Biological 
Invasions Center (Panov, V., Dianov, M., Lobanov, A. \& Shestakov, V., eds.) http://www.zin.ru/projects/invasions/gaas/aliens3r.htm

Panov, V. E., Krylov, P. I. \& Telesh, I. V. 1999b. The St. Petersburg harbour profile. In Initial Risk Assessment of Alien Species in Nordic Coastal Waters (Gollasch, S. \& Leppäkoski, E., eds.), Nord, 8, 225-244. Nordic Council of Ministers, Copenhagen.

Panov, V. E., Timm, T. \& Timm, H. 2000. Current status of an introduced Baikalian amphipod, Gmelinoides fasciatus (Stebbing), in the littoral communities of Lake Peipsi. Proc. Estonian Acad. Sci. Biol. Ecol., 49, 71-80.

Panov, V. E., Golubkov, S. M. \& Orlova, M. I. 2001. Littoral zone research in the Neva estuary (eastern Gulf of Finland): history and perspectives. Proc. Estonian Acad. Sci. Biol. Ecol., 50, 194-199.

Panov, V. E., Alimov, A. F., Golubkov, S. M., Orlova, M. I. \& Telesh, I. V. 2002a. Environmental problems and challenges for the coastal zone management in the Neva estuary (eastern Gulf of Finland). In Baltic Coastal Ecosystems: Structure, Function and Coastal Zone Management (Schernewski, G. \& Schiewer, U., eds.), pp. 171-184. CEEDES-Series, Springer Publ., Berlin.

Panov, V., Gollasch, S., Leppäkoski, E., \& Olenin, S. 2002b. International cooperation in aquatic invasive species research, information exchange and management in Europe. Aquat. Invaders, 13(4), 1-5.

Raaymakers, S. (ed.) 2002. Baltic Regional Workshop on Ballast Water Management, Tallinn, Estonia, 22-24 Oct 2001: Workshop Report. GloBallast Monograph Ser., No. 2. IMO, London.

Regional Biological Invasions Center. 2002a. Panov, V. E., Dianov, M. B., Lobanov, A. L. \& Shestakov, V. (eds.) Projects. http://www.zin.ru/projects/invasions/gaas/aa_proj.htm

Regional Biological Invasions Center. 2002b. Panov, V. E., Dianov, M. B., Lobanov, A. L. \& Shestakov, V. (eds.) Interactive Geographical Information System for Documentation and Mapping of Alien Species Distribution. http://www.zin.ru/projects/invasions/gaas/invader/invader.htm

Rumyantsev, V. A. 1999. The Gulf of Finland - main problems of the first quarter of XXI century. In Gulf of Finland under Anthropogenic Impact (Rumyantsev, V. A. \& Drabkova, V. G., eds.), pp. 355-363. St. Petersburg (in Russian).

Sprules, W. G., Riessen, H. P. \& Jin, E. H. 1990. Dynamics of the Bythotrephes invasion of the St. Lawrence Great Lakes. J. Great Lakes Res., 16, 346-351.

Statistical Analyses of Baltic Maritime Traffic. 2002. Report by VTT Technical Research Centre of Finland No VAL34-012344. http://www.vtt.fi/val/val3/val34/seastat/seastatkotisivu.htm

Telesh, I. V., Bolshagin, P. V. \& Panov, V. E. 2001. Quantitative estimation of the impact of alien species Cercopagis pengoi (Crustacea: Onychopoda) on the structure and functioning of plankton community in the Gulf of Finland, Baltic Sea. Dokl. Akad. Nauk, 377(3), 427-429 (in Russian).

Valovirta, I. \& Porkka, M. 1996. The distribution and abundance of Dreissena polymorpha (Pallas) in the eastern Gulf of Finland. Mem. Soc. Fauna Flora Fenn., 72, 63-78.

Winkler, H. M. \& Debus, L. 1996. Is the polychaete Marenzelleria viridis an important food item for fish? In Proceedings of the 13th Symposium of Baltic Marine Biologists (August 31September 4, 1993, Jurmala, Latvia), pp. 147-151.

Zmudzinski, L. 1996. The effect of the introduction of the American species Marenzelleria viridis (Polychaeta, Spionidae) on the benthic ecosystem of Vistula Lagoon. In Proceedings of 29th European Marine Biology Symposium (August 29-September 2, 1994 Vienna, Austria). Marine Ecol., 17(1-3), 221-226.

Zmudzinski, L., Chubarova-Solovjeva, S., Dobrovolski, Z., Gruszka, P., Olenin, S. \& Wolnomiejski, N. 1996. Expansion of the spionid polychaete Marenzelleria viridis in the southern part of the Baltic Sea. In Proceedings of the 13th Symposium of Baltic Marine Biologists (August 31September 4, 1993, Jurmala, Latvia), pp. 127-129. 


\title{
Võõrliikide introduktsioonid Soome lahe idaosas: hetkeolukord ja võimalikud kontrollmeetmed
}

\author{
Vadim E. Panov, Dmitry E. Bychenkov, Nadya A. Berezina \\ ja Alexey A. Maximov
}

\begin{abstract}
Viimased uuringud on näidanud, et Soome lahe idaosa tuleks klassifitseerida Läänemere ühe riskipiirkonnana; seda suure introduktsioonide hulga, võõrliikide negatiivse mõju ning ekspordile suunatud laevanduse kiire arengu tõttu. Uuritaval alal on viimase kahekümne aasta jooksul naturaliseerunud vähemalt 14 võõrliiki. Ehkki võõrliikidel on oluline roll rannikumere koosluste struktuurielemendina ja nende funktsioneerimisel, puuduvad selle kohta põhjalikumad uuringud. Uute sadamate ehitamine suurendab merre sattuva ballastvee hulka ning selle kaudu ka uute tulnukliikide introduktsioonide sagedust. Siit tulenevalt on vaja välja arendada efektiivsed kontrollmeetmed olemasolevate tulnukliikide ohjamiseks ning uute introduktsioonide vältimiseks.
\end{abstract}

